\title{
Effects of Sertoli Cell Transplantation on Spermatogenesis in Azoospermic Mice
}

\author{
Sanaz Ziaeipour ${ }^{a} \quad$ Behnaz Ahrabi ${ }^{a}$ Parvaneh Naserzadeh ${ }^{b} \quad$ Abbas Aliaghaei $^{a}$ \\ Ensieh Sajadia Hojjat-Allah Abbaszadeh ${ }^{a}$ Abdollah Aminia Shabnam Abdic,d \\ Shahram Darabie Mohammad-Amin Abdollahifara \\ aDepartment of Biology and Anatomical Sciences, School of Medicine, Shahid Beheshti University of \\ Medical Sciences, Tehran, Iran, bDepartment of Pharmacology and Toxicology, Faculty of Pharmacy, \\ Shahid Beheshti University of Medical Sciences, Tehran, Iran, 'Students Research Committee, \\ Department of Pharmacology and Toxicology, Faculty of Pharmacy, Shahid Beheshti University \\ of Medical Sciences, Tehran, Iran, dDepartment of Anatomical Sciences, School of Medicine, Azad \\ University of Medical Sciences, Tehran, Iran, e'Cellular and Molecular Research Center, Qazvin University \\ of Medical Sciences, Qazvin, Iran
}

\section{Key Words}

Sertoli cells • Spermatogenesis • Busulfan • Genes • Reproductive

\begin{abstract}
Background/Aim: The aim of this study was to evaluate the potential and significant applications of Sertoli cells (SCs) transplantation, and to explore the effect of transplantation on spermatogenesis process, in azospermic mice. Methods: In this study, we utilized 18 adult mice $(28-30 \mathrm{~g})$, divided into four experimental groups: (1) control, (2) vehicle (DMSO 2\%) $(10 \mu \mathrm{l})(3)$ busulfan and (4) busulfan+ SCs $(1 \times 104$ cells/ $\mu \mathrm{L})$. SCs were isolated from the testis of 4 -week-old mouse and after using anesthetics, $10 \mu \mathrm{l}$ of SCs suspension $(1 \times 104 \mathrm{cells} / \mu \mathrm{L})$ was injected over 3-5 min, into each testis and subsequently, sperm samples were collected from the tail of the epididymis. Afterward, the animals were euthanized and testis samples were taken for histopathology experiments, and RNA extraction, in order to examine the expression of c-kit, STRA8 and PCNA genes. Results: Our data showed that SCs transplantation could notably increase the total sperm count and the number of testicular cells, such as spermatogonia, primary spermatocyte, round spermatid, SCs and Leydig cells, compared to the control, DMSO and busulfan groups. Furthermore, the result showed that the expression of c-kit and STRA8 were significantly decreased in busulfan and busulfan/SCs groups, at 8 weeks after the last injection $(p<0.001)$, but no significant decrease was found for PCNA, compared to the control and DMSO groups $(P<0.05)$. Conclusion: These findings suggest that SCs transplantation may be beneficial as a practical approach for therapeutic strategies in reproductive and regenerative medicine. We further highlighted the essential applications that might provide a mechanism for correcting fertility in males, suffering from cell deformity.




\section{Cellular Physiology Cell Physiol Biochem 2019;52:421-434 \\ \begin{tabular}{ll|l} 
and Biochemistry & $\begin{array}{l}\text { DOl: 10.33594/000000030 } \\
\text { Published online: } 8 \text { March } 2019\end{array}$ & $\begin{array}{l}\text { C) } 2019 \text { The Author(s). Published by } \\
\text { Cell Physiol Biochem Press GmbH\&Co. KG }\end{array}$
\end{tabular} \\ Ziaeipour et al.: Sertoli Cell Transplantation}

\section{Introduction}

Spermatogenesis or seminiferous epithelial cycle is a complex and extraordinarily productive process, including the mitosis, meiosis and spermiogenesis of spermatogonia, spermatocytes and spermatids, respectively. In addition, it affects the pathogenesis mechanisms of the cellular process, including the program of various developmental stages of the germ cells. In parallel and at the beginning, by meiotic division, it differentiates to spermatocytes cells and afterwards through meiosis, these cells transform to round spermatids and eventually spermatozoa will be released into the lumen, via elongated spermatids [1-7].

All these spermatogenesis processes commonly occur in the enclosed microenvironment pool in germ cell development that are deployed in the seminiferous tubule of the testis [811]

The whole process of spermatogenesis relies on functional interplays, among germ cells and somatic, supporting cells (Sertoli cells (SCs), involving a complex classification of hormones, cytokines and vitamins $[12,13]$. SCs or "mother cells" or "nurse cells" play a principal role in regulating and controlling spermatogenesis by physiological and structural contacts, immunological and nutritional support, notably it can be baldly transformed into Leydig cells, and also changed to the neural stem cells of morphologic, phenotypic and functional type [14-17]. In addition, these cells have the ability for self-renewal, proliferation and spermatogonial stem cell differentiation, due to having a crucial component of different factors, including glial cell-derived neurotrophic factor (GDNF), fibroblast growth factor 2 (FGF2), kit ligand (KITL), activin A and bone morphogenic protein 4 (BMP4). Furthermore, $\mathrm{SC}$ function is strongly controlled by FSH and testosterone signaling. Moreover, SCs are engineered to produce specific proteins that restitute the metabolic function of the cell. Thus, SCs can be utilized in the modeling of diseases and regenerative medicine [6, 17-22].

Multiple reports of in vivo studies regarding gene therapy, using SC, independently suggested that this cell could invert the infertile phenotype in "Steel" mice [23-25]. In addition, another study by Zhang et al. (2007) revealed that donor SC from immature rats, colonized within the seminiferous tubules, but they have not found the effects of SC on spermatogonial differentiation [26]; however, the successes in these models may proposes that in vivo SC gene remedies could be expanded to treat infertility of men with somatic defect [27].

In this report, in order to elucidate the potency of SC and to explore its potential role, we highlighted the potential and significant applications of SC transplantation in azospermic mice, and examined the effect of transplantation on spermatogenesis process.

\section{Materials and Methods}

\section{Animal models}

In this study, 40 adult mice 8 weeks of age, weighing 28-30 g were used. The animals were purchased from the laboratory animal center of Pasteur Institute, Tehran, Iran. The Ethics Committee of the University approved the animal experiment (IR. SBMU. SM.REC.1396.184). The mice were divided into four experimental groups: (1) control, (2) vehicle (DMSO 2\%) (10 $\mu$ l) (3) busulfan and (4) busulfan+ SCs $\left(1 \times 10^{4}\right.$ cells/ $\mu \mathrm{L}$ ). Each group harbored ten mice, housed under standard conditions (room temperature $22^{\circ} \mathrm{C}-24^{\circ} \mathrm{C}$ and the 12:12 hour light-dark schedule). The mice had free access to water and food.

\section{Busulfan treatment}

Mice were induced with Azospermia and oligospermia, by injection of a single dose of $40 \mathrm{mg} / \mathrm{kg}$ busulfan (Sigma-Aldrich Product Number B2635), intraperitoneally. All mice were kept for 8 weeks after the busulfan injection, and then the sperm was analyzed. 


\section{Cellular Physiology Cell Physiol Biochem 2019;52:421-434 \begin{tabular}{ll|l} 
and Biochemistry & $\begin{array}{l}\text { DOl: 10.33594/000000030 } \\
\text { Published online: } 8 \text { March 2019 }\end{array}$ & $\begin{array}{l}\text { O } 2019 \text { The Author(s). Published by } \\
\text { Cell Physiol Biochem Press GmbH\&Co. KG }\end{array}$ \\
\cline { 2 - 3 }
\end{tabular}

\section{Isolation and culture of Sertoli cells}

The SCs were isolated from testis of 4-week-old male mice. Then, enzymatic digestion and decapsulation was performed, using $0.25 \%$ trypsin (Sigma) and $0.1 \%$ collagenase (Sigma, type V) at $37^{\circ} \mathrm{C}$. Then, the SCs were transferred into cell culture flasks and kept in the cell culture incubator. After $24 \mathrm{~h}$, the cell culture flasks were washed to eliminate debris. After $48 \mathrm{~h}$, the hypotonic cells were treated for 2.5 minutes with 20 $\mathrm{mM}$ Tris- $\mathrm{HCl}(\mathrm{pH} \mathrm{7.4)}$ ), to lyse any residual germ cells and to get SCs with the purity of $>95 \%$.

\section{Labeling of SCs with Hoechst}

We applied Hoechst solutions for labeling SCs. First, $5 \mu$ l of Hoechst 33258 (Sigma) solutions added to $1 \mathrm{ml}$ of serum-free cell suspension $\left(1 \times 10^{6}\right.$ cells $\left./ \mathrm{mL}\right)$. Then, it was incubated for 20 minutes at $37^{\circ} \mathrm{C}$ to prepare uniform labeling. Following the centrifuge and re-suspension of cells in a warm medium, labeled SCs suspension was ready for transplantation. The cells from the first labeled passage were collected, when they reached to $90 \%$ confluency, and then washed with PBS (Fig. 1).

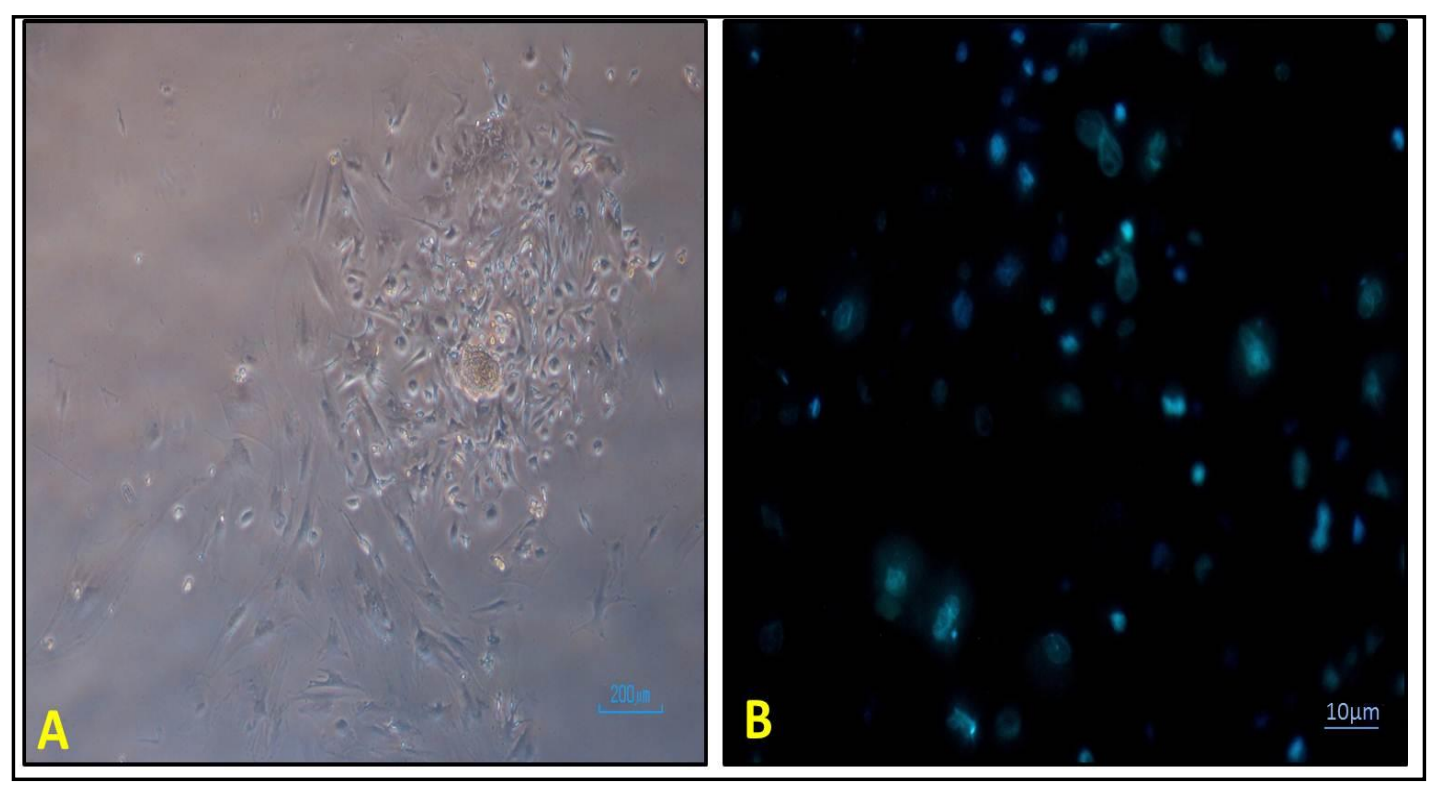

Fig. 1. (A) Sertoli Cells after 7days culture (B) Fluorescent labeling with Hoechst for Sertoli cells culture.

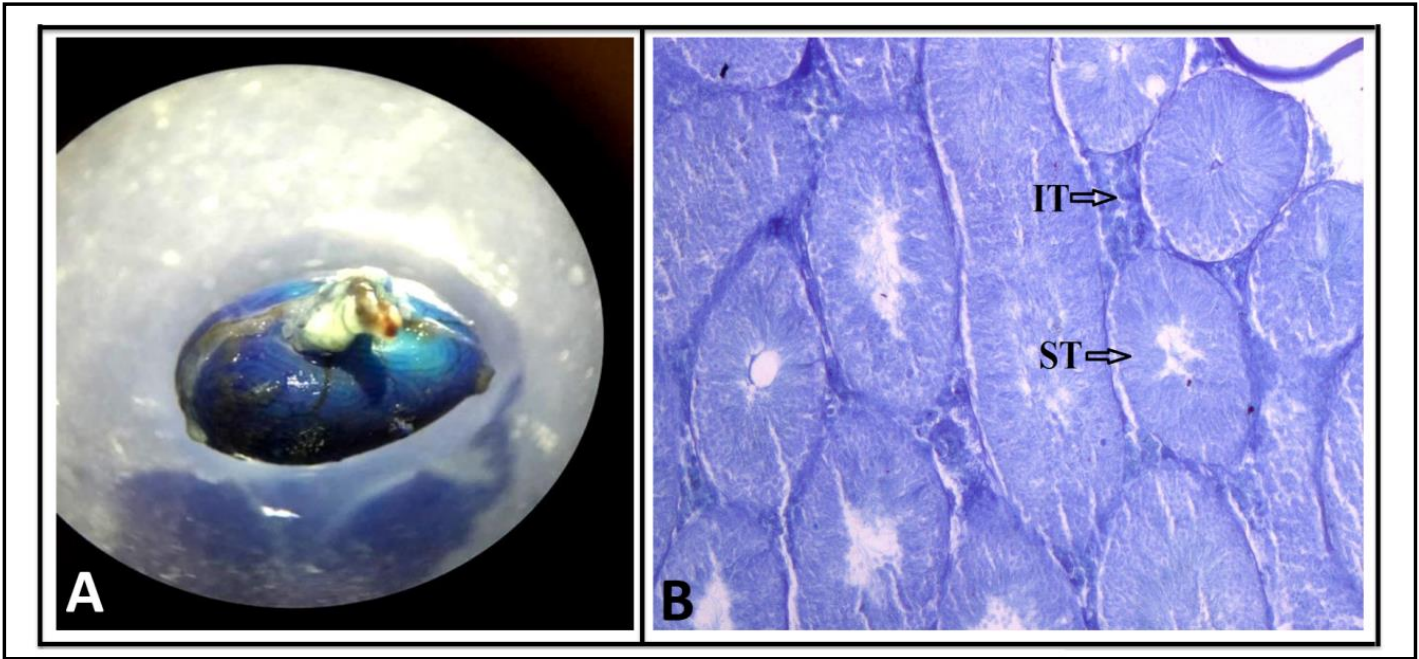

Fig. 2. (A) Toluidine blue dye was injected in testis as control. (B) Blue staining indicates seminiferous tubule (ST) and interstitial tissue (IT). 


\section{Cellular Physiology Cell Physiol Biochem 2019;52:421-434 \\ \begin{tabular}{cc|c|c|}
\hline DOI: 10.33594/000000030 & (O 2019 The Author(s). Published by \\
\hline
\end{tabular} \\ and Biochemistry Published online: 8 March 2019 Cell Physiol Biochem Press GmbH\&Co. KG \\ Ziaeipour et al.: Sertoli Cell Transplantation}

\section{Transplantation}

Before transplantation of SC, in order to examine the trace of injection, toluidine blue dye was injected in testis, as a control. After reassurance of suitable injection site, mice in the experimental group were anesthetized by ketamine $(100 \mathrm{mg} / \mathrm{kg})$ and xylazine $(5 \mathrm{mg} / \mathrm{kg})$. Then, $10 \mu \mathrm{l}$ of SCs suspension $\left(1 \times 10^{4} \mathrm{cells} /\right.$ $\mu \mathrm{L}$ ) was injected over 3-5 min, into each testis (Fig. 2).

\section{Sperm collection}

Sperm samples were collected from the tail of the epididymis and then transferred to the $1 \mathrm{ml}$ of Ham's F-10 media (Sigma-Aldrich Product Number N6635). After incubation at $37^{\circ} \mathrm{C}$ for 20 minutes, $10 \mu \mathrm{l}$ of the sample was placed on a slide and sperm motility was observed. The sperm count was measured by counting chamber. For examination of morphology, the sperm smear was prepared for analysis, placed on a slide, air dried at room temperature, and fixed in methyl alcohol. Then, the sample was stained with Diff-Quik.

\section{Stereological study}

On days of sampling, animals were euthanized with ether and their testes were collected and fixed in paraformaldehyde $4 \%$. After fixation, samples were sectioned by rotary microtome into $5 \mu \mathrm{m}$ thickness slices, stained with hematoxylin and eosin ( $\mathrm{H} \& \mathrm{E})$, and examined by light microscopy.

\section{Estimating the volume of testis}

Total volumes of the testis and interstitial tissue were measured by the Cavalieri method. The Cavalieri method [28] was used as an estimator of the testis volume. Thus, 8-10 sections were selected, using a systematic uniform random sampling. The image of each section was evaluated, using the stereological software and a video-microscopy system, made up of a microscope (Nikon, E-200, Japan), linked to a video camera. The volume of the testis was estimated by the following formula [29, 30]:

$$
\mathrm{V}_{\text {total }}=\sum \mathrm{P} \times \mathrm{t} \times \frac{\mathrm{a}}{\mathrm{p}}
$$

In this formula $\Sigma \mathrm{P}$ is the total points, hitting the testis sections, a/p is the area associated with each point, and $t$ is the distance between the sampled sections.

\section{Estimating the length of seminiferous tubules}

To estimate the length of seminiferous tubules, six random fields from sections were selected and the number of the selected seminiferous tubule profiles was counted, using an unbiased counting frame [31-33]; thus, an average number of seminiferous tubules per testis, was estimated. The length density of seminiferous tubules was also estimated, using the following formula [29, 30]:

$$
\mathrm{L}_{\mathrm{v}}=\frac{2 \times \sum \mathrm{Q}}{\sum \mathrm{P} \times \frac{\mathrm{a}}{\mathrm{f}}}
$$

In this formula $\Sigma Q$ is the total number of the seminiferous tubules, $\mathrm{a} / \mathrm{f}$ is the area per frame and $\Sigma \mathrm{P}$ is the total points superimposed on the testis tissue. The total length of the seminiferous tubules was estimated by multiplying the length density (Lv) by the total volume of the testis.

\section{Estimating the number of spermatogonia, spermatocyte, spermatid, SCs and Leydig cells}

The number of spermatogonia, primary spermatocyte, spermatid, SCs and Leydig cells were determined, using the optical dissector method and an unbiased counting frame. The position of the microscopic fields was selected by systematic, uniform random sampling, with moving the stage in equal distances in $\mathrm{x}$ - and $\mathrm{y}$-directions. The focal plane was moved downwards in z-direction. Then, a microcator was attached to the stage of the microscope (Heidenhain, Germany) to measure the $\mathrm{z}$-axis traveling

Table 1. Primers design

\begin{tabular}{cccc}
\hline Genes & Primer sequences & Product size & TM $\left({ }^{\circ} \mathrm{C}\right)$ \\
\hline c-Kit & F: GCATCACCATCAAAAACGTG & $332 \mathrm{bp}$ & 58 \\
STAR & F: GCCAGAATGTATTCCGAGAA & $121 \mathrm{bp}$ & 57 \\
PCNA & F: GATGTGGAGCAACTTGGAAT & $160 \mathrm{bp}$ & 53 \\
GAPDH & F: ATCACTGCCACTCAGAAGACTG & $293 \mathrm{bp}$ & 60 \\
\hline
\end{tabular}




\section{Cellular Physiology Cell Physiol Biochem 2019;52:421-434

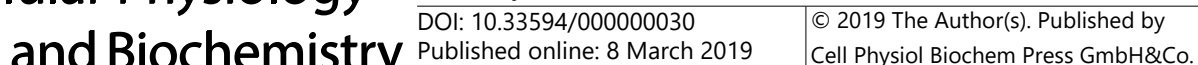 \\ Ziaeipour et al.: Sertoli Cell Transplantation}

(depth). Using the following equation, the number density (Nv) of different types of cells was estimated, using the following formula $[29,30]$ :

$$
N v=\left[\frac{\sum Q^{-}}{\sum P \times \frac{a}{f} \times h} \times \frac{t}{B A}\right]
$$

In this formula $\Sigma \mathrm{Q}$ is the total number of the counted cells, $\mathrm{h}$ is the tissue thickness considered for counting, a/f is the area per frame and $\Sigma \mathrm{P}$ is the total number of the counting frames in all fields. $\mathrm{H}$ is the height of the dissector, $t$ is the real section thickness measured, and using the microcator, when the $Q$ - is counted and BA is the tissue section thickness. The result of the equation was then multiplied by the total volume of the testis, to obtain the total number of cells.

$$
\mathrm{N}_{\text {(total) }}=\mathrm{N}_{\mathrm{V}} \times \mathrm{V}_{\text {(final) }}
$$

\section{Tunnel assay}

DNA fragmentation refers to apoptosis markers. Terminal deoxynucleotidyl transferase dUTP nick and labeling (Tunnel) is one method to detect DNA fragmentations. After treatment, the tissues were fixed and embedded in paraffin, then sectioned on glass slides, and stained according to the Tunnel protocols. Finally, Tunnel-positive cells were quantified in 10 sections per testis.

\section{RNA extraction}

The High Pure RNA Isolation kit was considered to isolate the total RNA from the mice testes, following the manufacturer's instructions (Roche, Basel, Switzerland). Subsequently, the collected RNA samples were treated with DNase I enzyme. Afterward, the Nanodrop ND-1000 spectrophotometer (Thermo-Scientific, USA), with an absorbance of $260 \mathrm{~nm}$ and $280 \mathrm{~nm}$, and agarose gel electrophoresis (2\%) were used to evaluate the purity of total harvested RNA.

\section{Primer design}

All primers were designed, according to the Primer3Plus software, considering the exon-exon junction, to discriminate between cDNA and genomic DNA, when possible. Formerly, the PCR primers were evaluated by Primer-Blast tool on the NCBI site, www.ncbi.nlm.nih.gov/tools/primer-blast (Table 1).

\section{cDNA synthesis}

Onemicrogram of total RNA was used to synthesize the first strand complementary DNA (cDNA), using murine leukemia virus (MuLV) reverse transcriptase (Fermentas, Lithuania), in the presence of random hexamers and RNase inhibitor. The harvested cDNA was amplified by 35 cycles, using PCR Master Mix (Amplicon, Denmark). The products of PCR were tested by agarose gel (2\%) electrophoresis and envisioned by ethidium bromide stain.

\section{Quantitative real-time PCR}

For Quantitative real-time RT-PCR (qRT-PCR), specific primers were designed for c-kit, STRA8 and PCNA and glyceraldehyde-3-phosphate dehydrogenase (GAPDH), as an internal control for normalizing the values. Reactions were performed, using SYBR® Premix Ex Taq ${ }^{\mathrm{TM}}$ II (Takara Bio Inc, Japan) on a RotorGeneTM 6000 real-time PCR machine (Corbett Research, Qiagen, Germany). Initial denaturation was performed at $95^{\circ} \mathrm{C}$ for 15 minutes, followed by 45 cycles of denaturation at $95^{\circ} \mathrm{C}$ for 10 seconds, annealing under primer specific conditions, and extension at $72^{\circ} \mathrm{C}$ for 20 seconds. Comparative quantitation was performed between selected groups, using REST 2009 (Relative Expression Software Tool, Qiagen), based on PairWise Fixed Reallocation Randomization Test@C.21. To assess the relative abundance of mRNA, mean CT values were calculated from triplicate reactions, ran for each sample. Relative gene expression was then calculated, using the Pfaffl method [34]. Then, the obtained data were evaluated, using one-way ANOVA, followed by Fisher's LSD post-hoc comparisons.

\section{Statistical analysis}

In this study, the Kolmogorov-Smirnov test was applied to check the normality, and then a parametric approach was used to analyze the data. The stereological data was compared, using one-way ANOVA. The 
gene expression data obtained from Real-Time PCR was also analyzed by one-way ANOVA. All statistical work was performed in IBM SPSS statistics V21. Results were presented as mean \pm SD. The significance of comparisons was denoted by $\mathrm{p}<0.05$.

\section{Results}

\section{Total volume of testis and interstitial tissue}

The total volume of testis and interstitial tissue were significantly decreased in the mice, treated with busulfan, in comparison to the control and DMSO groups $(\mathrm{P}<0.001)$. Transplantation with SCs did not ameliorate the reduction of testis volume, compared to the control and DMSO groups, but the volume of interstitial tissue increased in mice, after transplantation with SCs, in comparison with the busulfan groups $(\mathrm{P}<0.02$; Fig. 3 and 4).

\section{Total length of seminiferous tubules}

The total length of seminiferous tubules was significantly reduced in the mice, treated with busulfan, in comparison to the control and DMSO groups $(\mathrm{P}<0.01)$. The total length of seminiferous tubules increased in mice, after transplantation with SCs, compared with the busulfan groups ( $\mathrm{P}<0.05$; Fig. 3 and 4$)$.

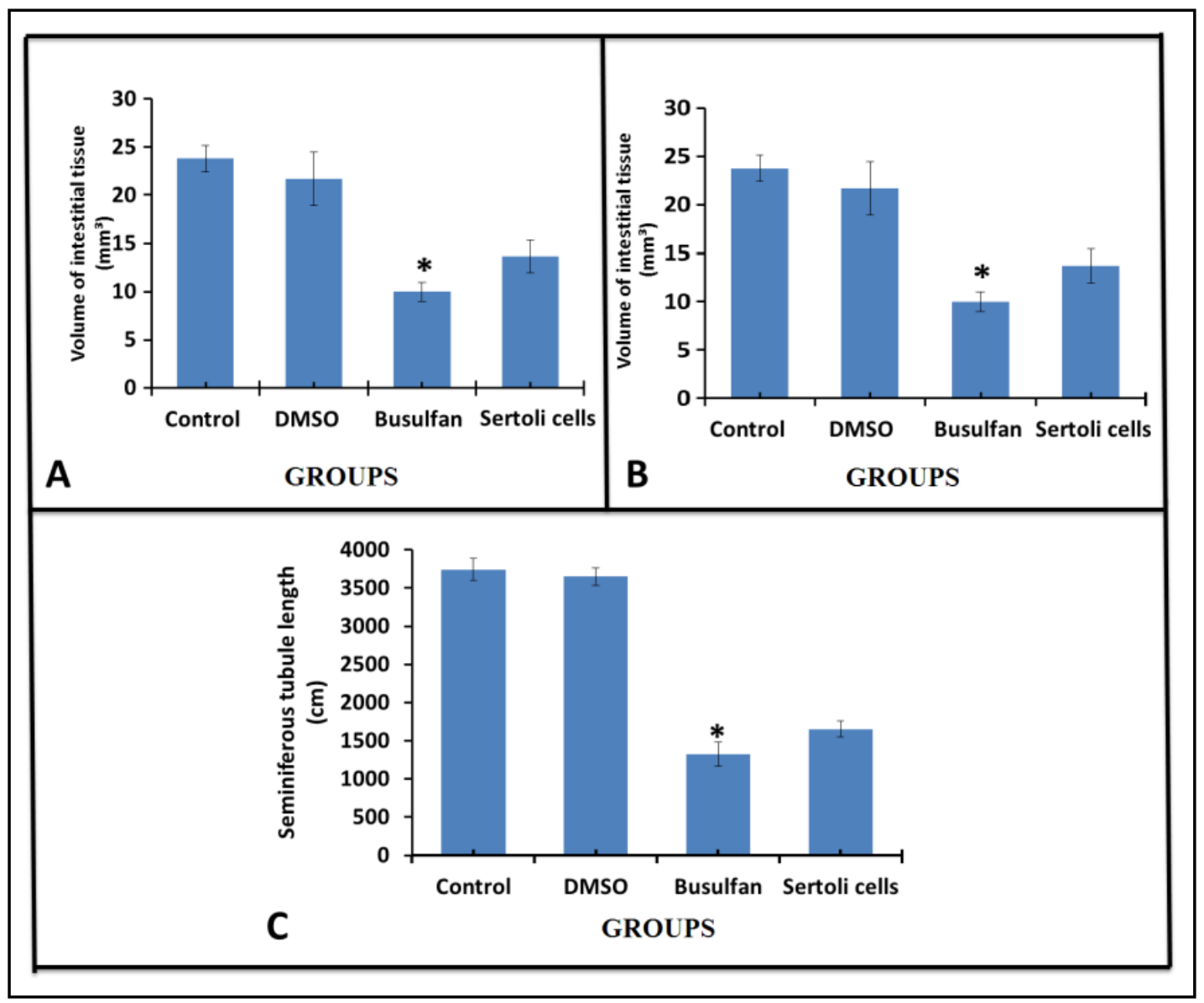

Fig. 3. (A, B) The total volume of testis and interstitial tissue in the different groups are shown. The significant difference between busulfan groups in comparison to the control and DMSO groups is indicated. ${ }^{*} \mathrm{p}<0.01$. (C) The total length of seminiferous tubules in the different groups are shown. The significant difference between busulfan groups in comparison to the control and DMSO groups is indicated. ${ }^{\mathrm{p}}<0.01$. 
Cellular Physiology and Biochemistry

Cell Physiol Biochem 2019;52:421-434

\begin{tabular}{l|l}
\hline DOl: $10.33594 / 000000030$ & (c) 2019 The Author(s). Published by
\end{tabular}

Ziaeipour et al.: Sertoli Cell Transplantation

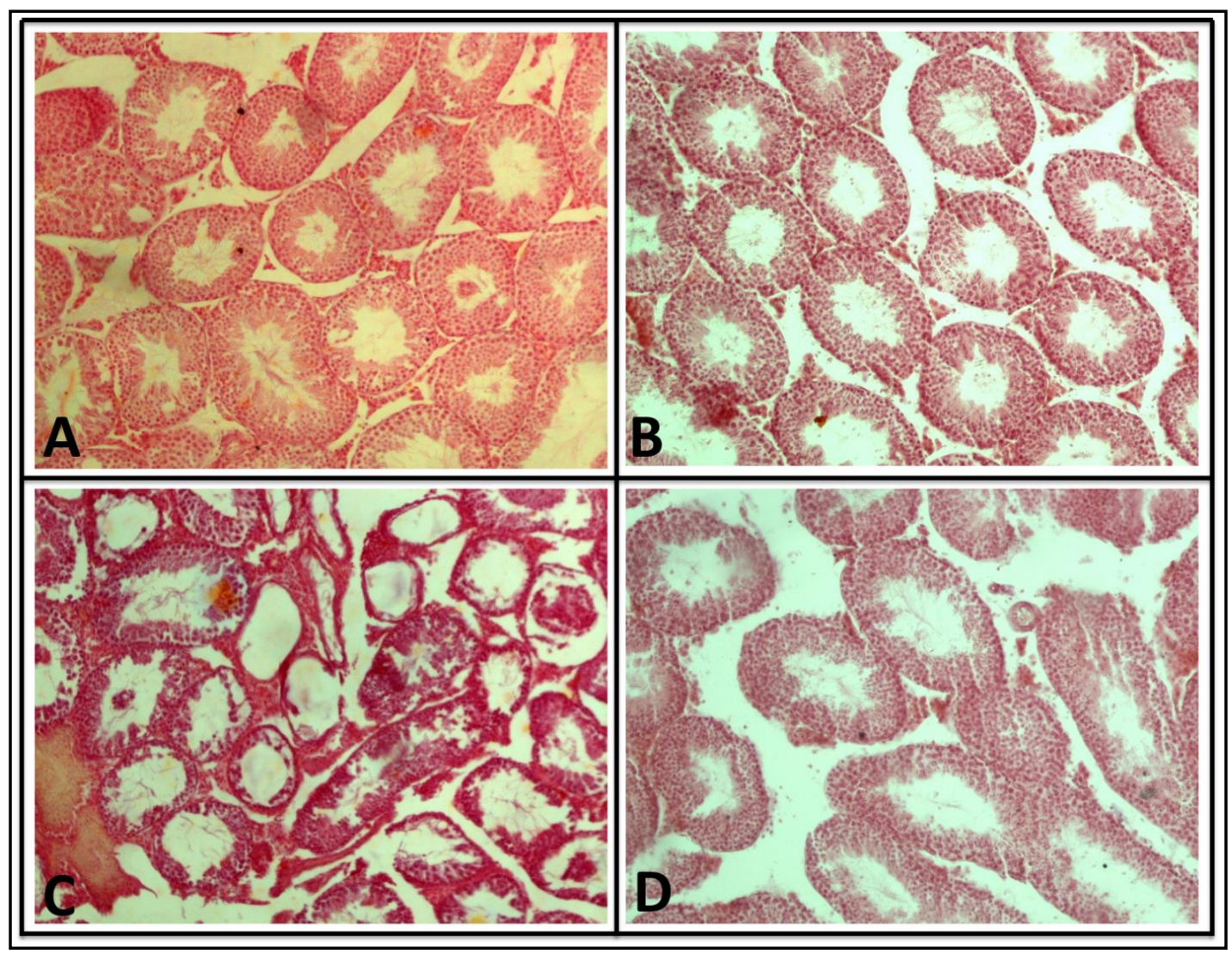

Fig. 4. Hematoxylin and eosin-stained histological Cross-sections of the seminiferous cords from Control groups (A), sham groups (B), 8 weeks after Busulfan injection (C), 8 weeks after Sertoli cells transplant (D).

Fig. 5. (A-E) The total number of spermatogonia, primary spermatocyte, round spermatid, Sertoli Cells and Leydig cells in the different groups are shown. The significant difference between busulfan groups in comparison to the control and DMSO groups is indicated. ${ }^{*} \mathrm{p}<0.01$.

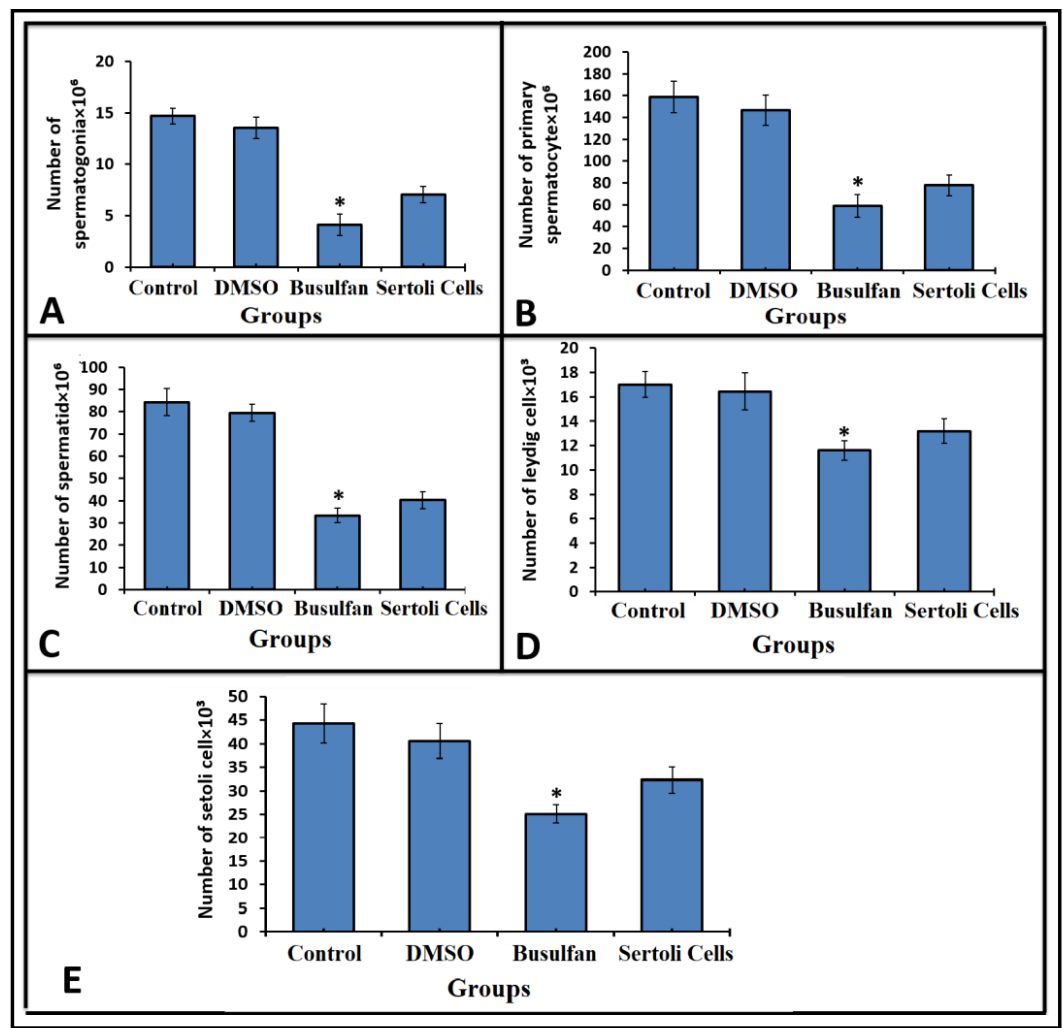




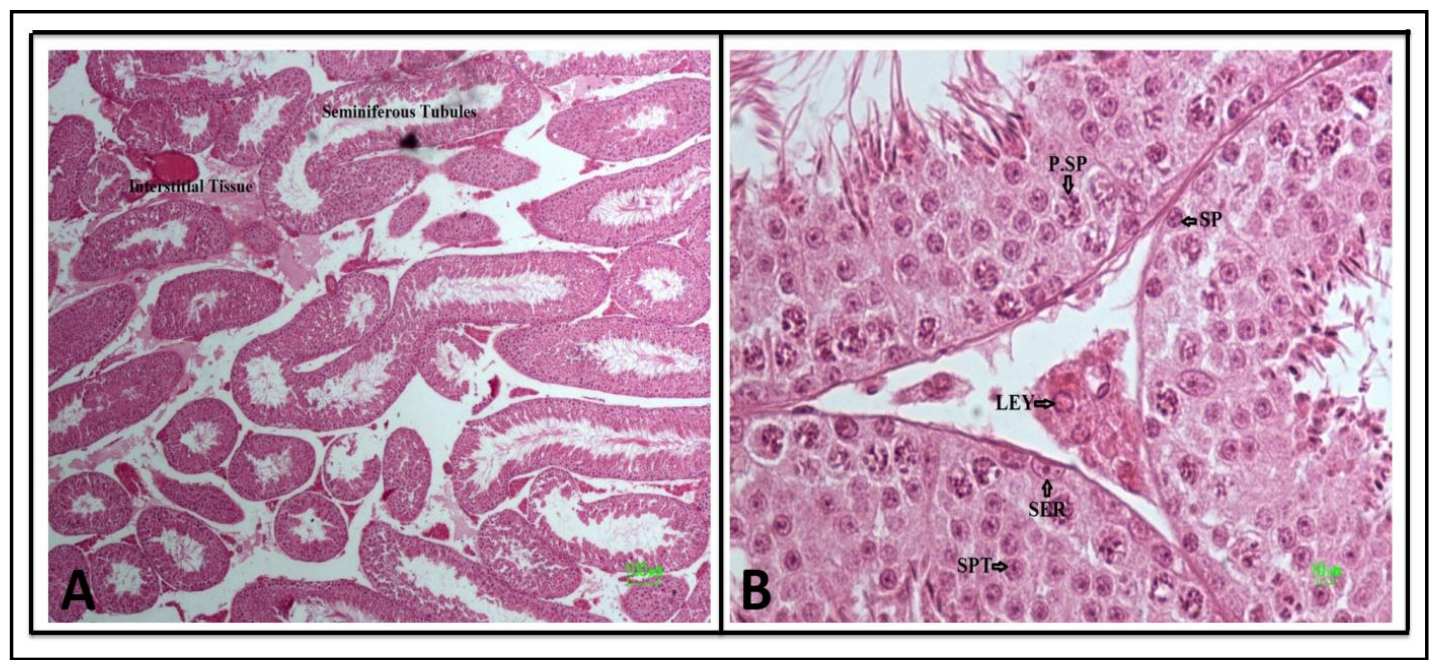

Fig. 6. Hematoxylin and eosin-stained histological Cross-sections of the seminiferous cords. Spermatogonia(SP), Primary spermatocyte (P. SP), Round spermatid (SPT), Sertoli cells (SER), Leydig cells (LEY).

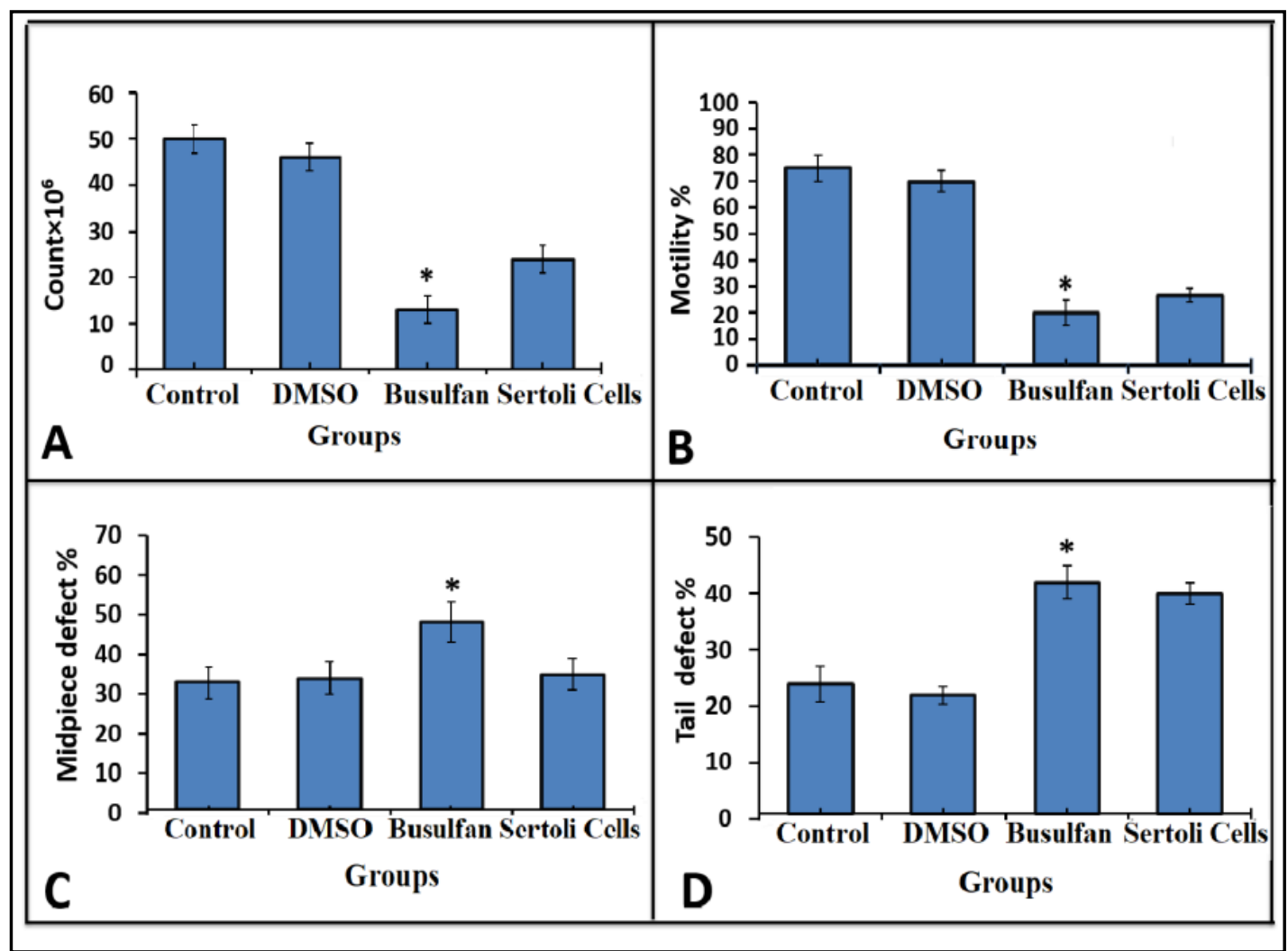

Fig. 7. (A-D) Total sperm count, motility and sperm mid-piece and tail defect in the different groups are shown. The significant difference between busulfan groups in comparison to the control and DMSO groups is indicated. ${ }^{*} \mathrm{p}<0.01$. 
Number of Spermatogonia, primary spermatocyte, round spermatid, Sertoli Cells and Leydig cells

The total number of spermatogonia, primary spermatocyte, round spermatid, SCs and Leydig cells in busulfan-induced groups was decreased, compared to the DMSO, SCs and control groups $(\mathrm{P}<0.01)$. Transplantation with SCs did not ameliorate the reduction of testis volume, in comparison with the control and DMSO groups, but the number of spermatogonia, primary spermatocyte, round spermatid, SCs and Leydig cells was increased, after transplantation of mice with SCs, in comparison with the busulfan groups $(\mathrm{P}<0.05$; Fig. 5 and 6).

\section{Total sperm count, motility and sperm mid-piece and tail defect}

Our data showed that the total sperm count in busulfan-induced animals was decreased, in comparison with the control, DMSO and SCs groups $(\mathrm{P}<$ 0.001). Busulfan produced an extreme significant reduction in sperm count in the busulfan groups, compared with the control and DMSO groups, but the sperm count after transplantation of mice with SCs showed significant improvement, in comparison with the busulfan groups $(\mathrm{P}<0.03)$. Our data show that the sperm motility also decreased in the busulfan groups in comparison to the control, DMSO and SCs groups $(\mathrm{P}<0.002)$. The SCs transplantation shows a significant improved sperm motility, in comparison with the busulfan groups $(\mathrm{P}<0.05)$.

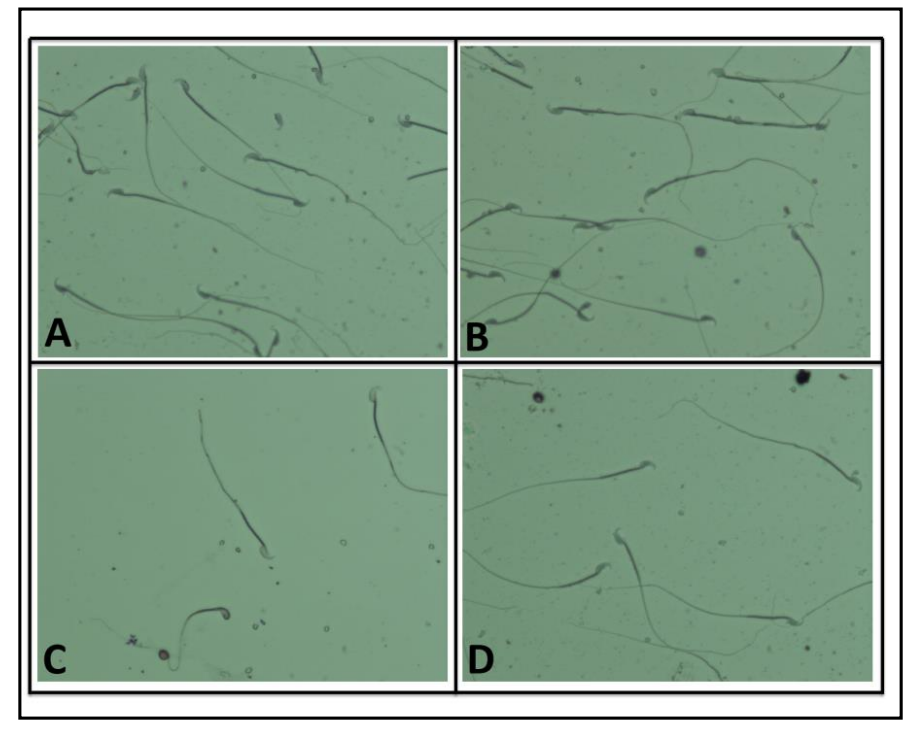

Fig. 8. Microscopic image of sperm sample was stained with DiffQuik. (A) Control groups, (B) DMSO groups, (C) Busulfan groups, (D) Sertoli cells groups.

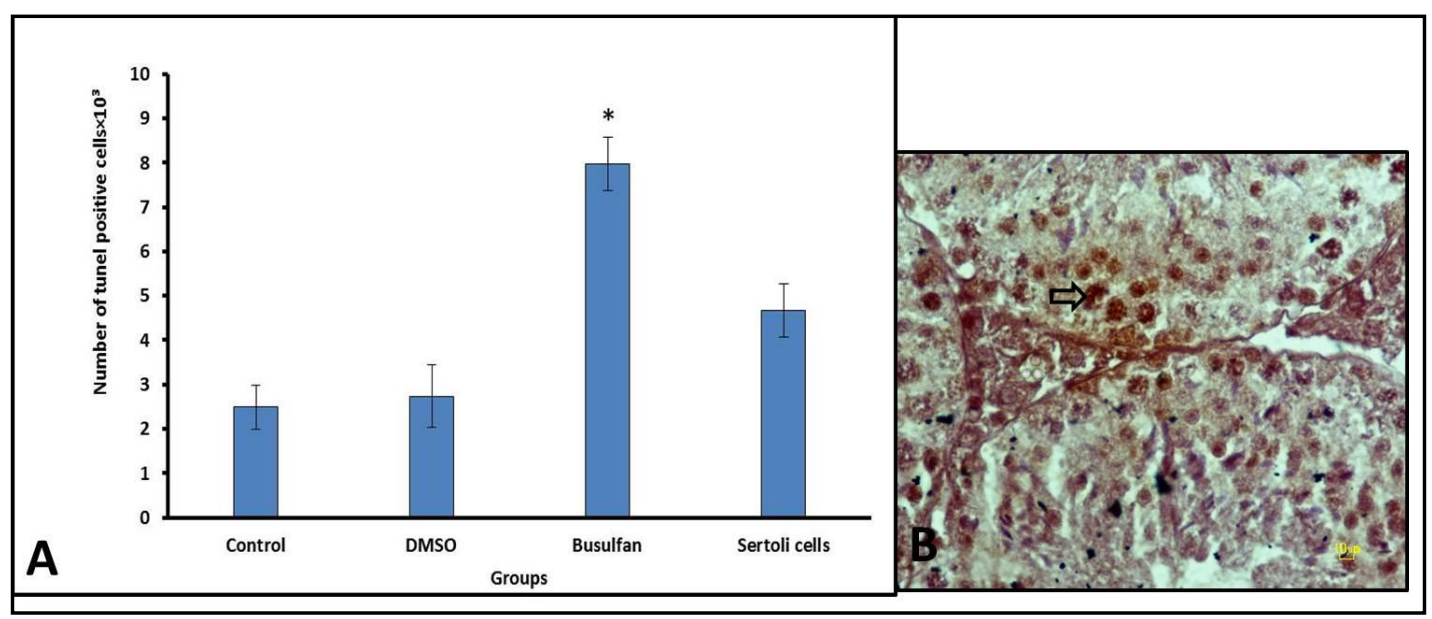

Fig. 9. (A) Total number of apoptotic cells in the different groups is shown. The significant difference between busulfan groups in comparison to the control and DMSO groups is indicated. ${ }^{*} p<0.01$. (B) Representative microphotographs of Tunnel assay. Tunnel detection of apoptotic cells in testes. Tunnel-positive cells are stained in brown (Arrows). 
The results showed a significant increase in the defects of the sperm mid-piece and tail in the busulfan groups, compared to the control, DMSO and SCs groups $(\mathrm{P}<0.001)$. The SCs transplantation shows a significant reduction in sperm mid-piece and tail, in comparison with the busulfan groups $(\mathrm{P}<0.01)$ (Fig. 7 and 8).

\section{Increased Apoptosis in Testis}

The effect of SCs transplantation on the apoptotic changes of sermatogenic cells was investigated by TUNEL assay. TUNEL-positive cell counts showed a significant increase in the apoptotic cells in the busulfan groups, in comparison with the control, DMSO and SCs groups $(\mathrm{P}<0.001)$ (Fig. 9 and Fig. 10).

\section{Expression levels of Ckit, STRA8 and PCNA}

The relative mRNA expression levels of c-kit, STRA8 and PCNA between different groups were normalized by control, and quantitated. As shown in the figure below, the levels of c-kit and STRA8 expression in rat testicular tissue were significantly decreased at 8 weeks, after the last injection $(\mathrm{p}<0.001)$, but there was not a distinct decrease for PCNA, compared to the control and DMSO groups $(\mathrm{P}<0.05)$. The relative mRNA expression levels of the indicated genes (c-kit, STRA8 and PCNA) between groups were presented in the Fig. 11.

\section{Discussion}

SCs have the potency to discharge several types of factors, which play fundamental roles in regulating the self-renewal, multiplication and spermatogonial stem cell differentiation,

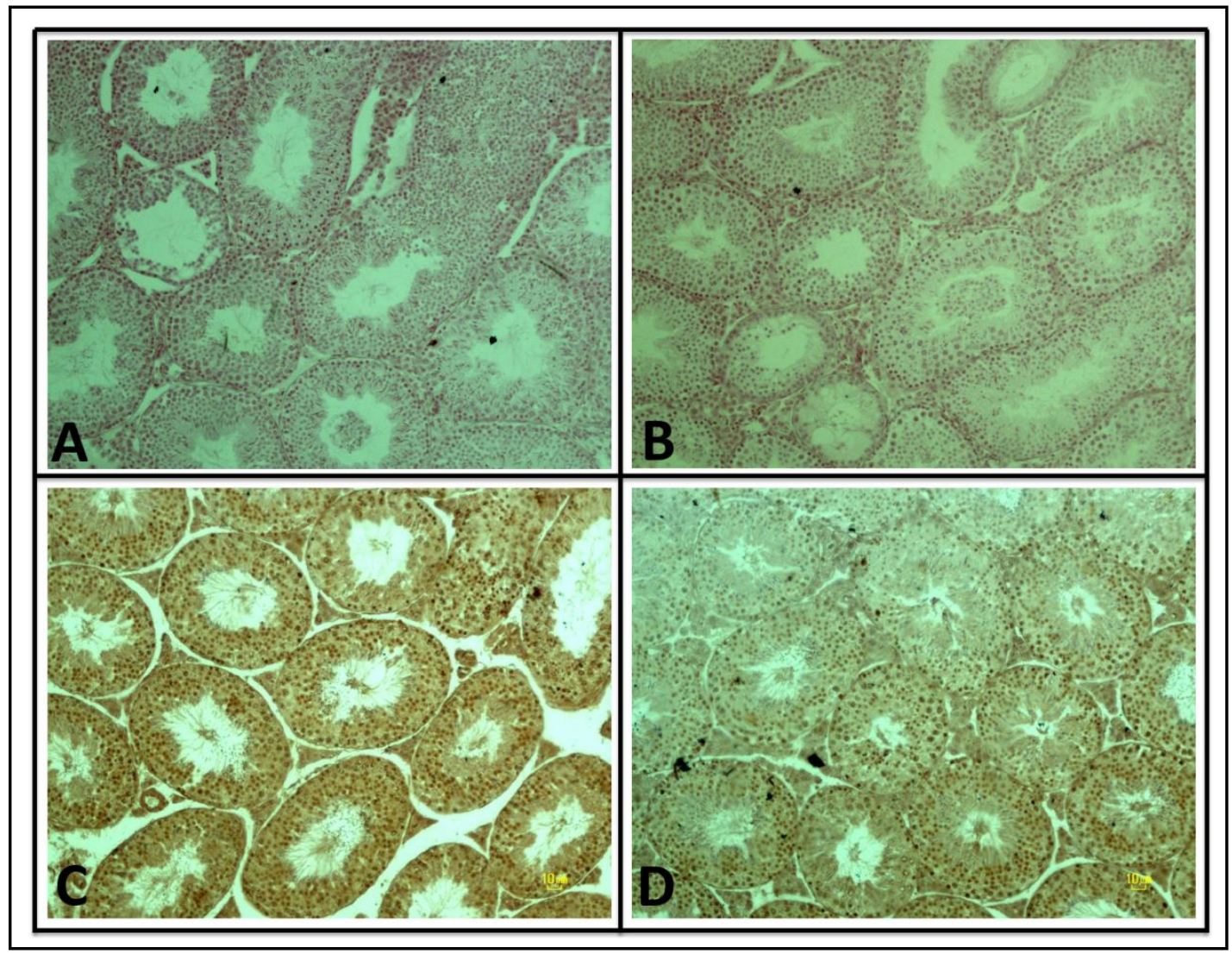

Fig. 10. TUNEL staining, histological Cross-sections of the seminiferous cords from Control groups (A), sham groups (B), after injection of Busulfan (C), after transplantation of Sertoli cells (D). 


\title{
Cellular Physiology Cell Physiol Biochem 2019;52:421-434 \begin{tabular}{ll|l} 
and Biochemistry $\begin{array}{l}\text { DOl. 33594/000000030 } \\
\text { Published online: } 8 \text { March 2019 }\end{array}$ & $\begin{array}{l}\text { O } 2019 \text { The Author(s). Published by } \\
\text { Cell Physiol Biochem Press GmbH\&Co. KG }\end{array}$ \\
\cline { 2 - 3 } &
\end{tabular} \\ Ziaeipour et al.: Sertoli Cell Transplantation
}

\begin{abstract}
Fig. 11. The graph show the relative mRNA expression levels of c-kit (red line), STRA8 and PCNA between different groups in the testis tissue; the relative mRNA expression was tested at 8 weeks after the last injection, as shown in graph, the relative mRNA expression of c-kit

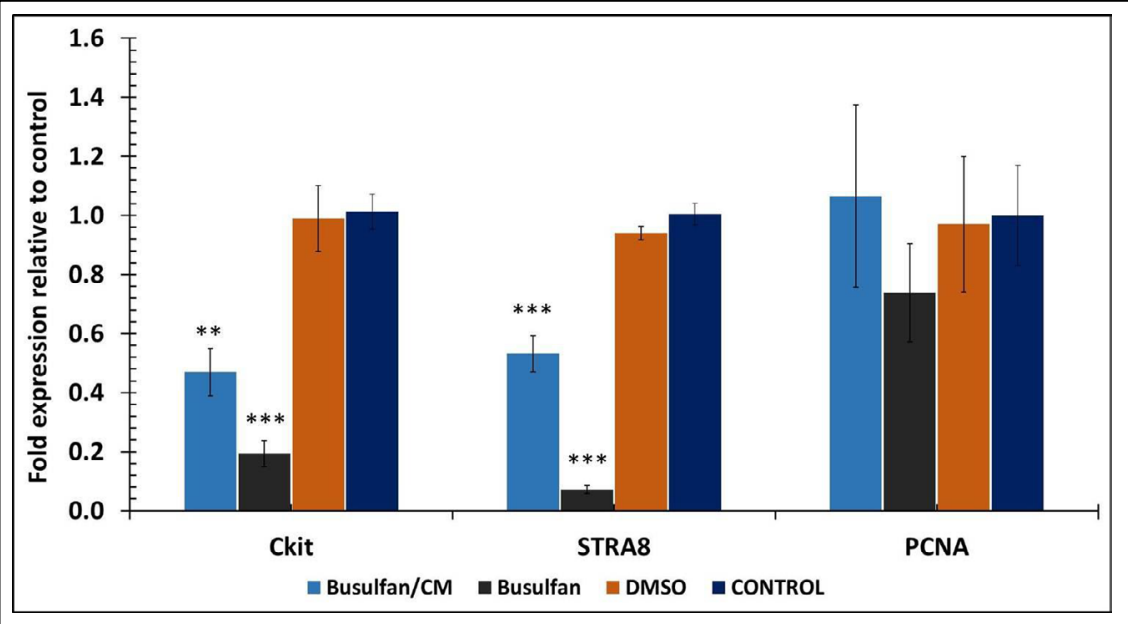
and STRA8 in testis tissue were decreased significantly after busulfan and busulfan/CM Injection compared to control and DMSO groups $\left(\mathrm{p}<0.000^{* * *}\right)$, this decrease was more dominant in the busulfan groups than busulfan/CM groups, and also, the alterations of relative expression for PCNA wasn't significant between experimental groups in compared to DMSO and control roups $(* * * \mathrm{p}<0.001)$.
\end{abstract}

during the spermatogenesis process. Therefore, nowadays having a greater consciousness about the role of SCs transplantation in spermatogenesis, will be necessary for the control of male fertility by the homeostasis and regulation of SCs function.

In this study, we found that SCs transplantation could notably increases the sperm count and the number of testicular cells, such as spermatogonia, primary spermatocyte, round spermatid, SCs and Leydig cells. In addition, we also observed a remarkable enhancement in sperm motility, compared to the control, DMSO and busulfan groups, suggesting that SCs may regulate cell mitosis and meiosis of human male germ cells. Furthermore, we also investigated the relative mRNA expression levels of the indicated genes in testicular tissue between the groups, demonstrating a reduction or no significant difference at the transcriptional level of mice SCs. Likewise, we have seen the volume of interstitial tissue increases in mice after the transplantation with SCs. The previous reports stating the effect of SCs implanted, on the development of testicular interstitium and tubular structures, our observation of the potency of SCs was consistent with those of previous studies [35-38].

On the other hand, similar to our present report, recent observations propose an extraordinary role for the populations of interstitial cell in formation of spermatogonial stem cell, in specific, associative monitorings from previous studies [36-38] have shown that transplanted SCs, support spermatogenesis within the testis seminiferous tubules or in the interstitium of the testis or stimulates partial recovery of spermatogenesis $[1,35$, 36, 39, 40-43]. In a study, Tesarik et al. indicated that short-term co-culture of germ cells with SCs could improve spermatogenesis [44], and another observation by Tajima et al. revealed that stimulating factors generated by SCs in co-culture system, could progress the spermatogonial stem cell differentiation [45]. In addition, Hue et al. utilized testis somatic cells for spermatogonial stem cell differentiation, and the germ cells could differentiate into spermatid in vitro. Their data revealed that SCs also stimulate differentiation in immortalized spermatogonial cell line [46]. Our findings consistent with previous studies, clearly demonstrate an improved in vitro differentiation in the presence of SCs. In parallel, Krawetz et al. (2009) expressed that the cytokines generated by SCs, play a significant role in the progression of spermatogonia and spermatocyte, the integrity of the immune system, and the function of the regulatory immune cells in the interstitium [47]. 


\section{Cellular Physiology Cell Physiol Biochem 2019;52:421-434

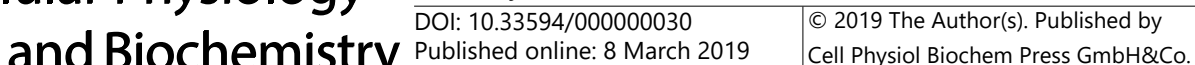 \\ Ziaeipour et al.: Sertoli Cell Transplantation}

\section{Conclusion}

Taken together, our findings clearly demonstrated that SCs could ameliorate spermatogonia cell proliferation and differentiation in vitro, through secretion of growth factors. SCs transplantation may be beneficial as an approach and new therapeutic strategies, for male infertility in reproductive and regenerative medicine. These cells can provide fundamental sources of different types of male germ cells and SCs, contributing to the determination of the genetic and epigenetic regulators, in controlling the spermatogonia mitosis and spermatocytes meiosis.

\section{Acknowledgements}

This research was supported by the Vice chancellor for Research of School of Medicine, Shahid Beheshti University of Medical Sciences, Tehran, Iran.

\section{Disclosure Statement}

The authors declare to have no competing interests.

\section{References}

1 Zhang Z, Shao S, Shetty G, Meistrich ML: Donor Sertoli cells transplanted into irradiated rat testes stimulate partial recovery of endogenous spermatogenesis. Reproduction 2009;137:497-508.

2 Meistrich ML, Shetty G: Inhibition of spermatogonial differentiationby testosterone. J Androl 2003;24;135148.

3 Kangasniemi M, Huhtaniemi I ,Meistrich ML: Failure of spermatogenesis to recover despite the presence of A spermatogonia in the irradiated LBNF1 rat. Biol Reprod 1996;54:1200-1208.

4 Russell L, Ettlin R, Sinha Hikim A, Clegg E: Histological and histopathological evaluation of the testis. Clearwater, FL, Cache River Press, 1990.

5 Oginuma M, Niwa Y, Chapman DL, Saga Y: Mesp2 and Tbx6 cooperatively create periodic patterns coupled with the clock machinery during mouse somitogenesis. Development 2008;135:2555-2562.

6 Wang H, Wen L, Yuan Q, Sun M, Niu M, He Z: Establishment and applications of male germ cell and Sertoli cell lines. Reproduction 2016;152:R31-R40.

7 Schlegel PN: Evaluation of male infertility. Minerva Ginecologica 2009;61:261-283.

- 8 Gassei K, Orwig KE: Experimental methods to preserve male fertility and treat male factor infertility. Fertil Steril 2016;105:256-266.

- 9 Tegelenbosch RA, de Rooij DG: A quantitative study of spermatogonial multiplication and stem cell renewal in the c3h/101 f1 hybrid mouse. Mutat Res 1993;290:193-200.

- 10 De Rooij DG, Grootegoed JA: Spermatogonial stem cells. Curr Opin Cell Biol 1998;10:694-701.

- 11 Phillips BT, Gassei K, Orwig KE: Spermatogonial stem cell regulation and spermatogenesis. Philos Trans R Soc Lond B Biol Sci 2010;365:1663-1678.

12 Raverdeau M, Gely-Pernot A, Féret B, Dennefeld C, Benoit G, Davidson I, Chambon P, Mark M, Ghyselinck NB: Retinoic acid induces Sertoli cell paracrine signals for spermatogonia differentiation but cell autonomously drives spermatocyte meiosis. Proc Natl Acad Sci USA 2012;109:16582-1657.

13 De Rooij DG, Russell LD: All you wanted to know about spermatogonia but were afraid to ask. J Androl 2000;21:776-798.

14 Hai Y, Hou J, Liu Y, Yang H, Li Z, He Z: The roles and regulation of Sertoli cells in fate determinations of spermatogonial stem cells and spermatogenesis. Semin Cell Dev Biol 2014;29:66-75.

15 Zhang L, Chen M, Wen Q, Li Y, Wang Y, Qin Y, Qin Y, Cui X, Yang L, Huff V: Reprogramming of Sertoli cells to fetal-like Leydig cells by Wt1 ablation. Proc Natl Acad Sci U S A 2015;112;4003-4008. 


\section{Cellular Physiology Cell Physiol Biochem 2019;52:421-434

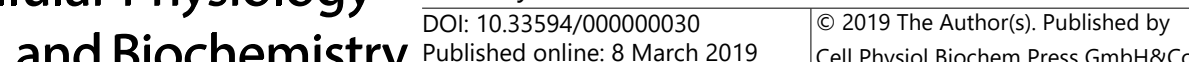 and Biochemistry Published online: 8 March 2019 Cell Physiol Biochem Press GmbH\&Co. KG \\ Ziaeipour et al.: Sertoli Cell Transplantation}

16 Sheng C, Zheng Q, Wu J, Xu Z, Sang L, Wang L, Guo C, Zhu W, Tong M, Liu L: Direct reprogramming of Sertoli cells into multipotent neural stem cells by defned factors. Cell Res 2012;22;208-218.

- 17 Kaur G, Thompson LA, Pasham M, Tessanne K, Long CR, Dufour JM: Sustained expression of insulin by a genetically engineered sertoli cell line after allotransplantation in diabetic BALB/c mice. Biol Reproduction 2014;90;109.

- 18 Boyer A, Yeh JR, Zhang X, Paquet M, Gaudin A, Nagano MC, Boerboom D: CTNNB1 signaling in sertoli cells downregulates spermatogonial stem cell activity via WNT4. PLoS One 2012;7:e29764.

- 19 Meng X, Lindahl M, Hyvönen ME, Parvinen M, de Rooij DG: Regulation of cell fate decision of undifferentiated spermatogonia by GDNF. Science 2000;287:1489-1493.

20 Goriely A, McVean GA, van Pelt AM, O’Rourke AW, Wall SA: Gain-of-function amino acid substitutions drive positive selection of FGFR2 mutations in human spermatogonia. Proc Natl Acad Sci USA 2005;102:60516056.

21 Schrans-Stassen BH, van de Kant HJ, de Rooij DG, Van Pelt AM: Differential expression of c-kit in mouse undifferentiated and differentiating type A spermatogonia. Endocrinology 1999;140:5894-5900.

22 Pellegrini M, Grimaldi P, Rossi P, Geremia R, Dolci S: Developmental expression of BMP4/ALK3/SMAD5 signaling pathway in the mouse testis: a potential role of BMP4 in spermatogonia differentiation. J Cell Sci 2003:116: 3363-3372.

- 23 Ikawa M, Tergaonkar V, Ogura A, Ogonuki N, Inoue K, Verma IM: Restoration of spermatogenesis by lentiviral gene transfer: offspring from infertile mice. Proc Natl Acad Sci USA 2002;99:7524-7529.

- 24 Kanatsu-Shinohara M, Ogura A, Ikegawa M, Inoue K, Ogonuki N, Tashiro K, Toyokuni S, Honjo T, Shinohara T: Adenovirus-mediated gene delivery and in vitro microinsemination produce offspring from infertile male mice. Proc Natl Acad Sci USA 2002;99:1383-1388.

25 Yomogida K, Yagura Y, Nishimune Y: Electroporated transgene-rescued spermatogenesis in infertile mutant mice with a sertoli cell defect. Biol Reprod 2002;67:712-717.

26 Zhang Z, Shao S, Meistrich M: The radiation-induced block in spermatogonial differentiation is due to damage to the somatic environment, not the germ cells. J Cell Physiol 2007;211;149-158.

27 Gassei K, Orwig KE: Experimental methods to preserve male fertility and treat male factor infertility. Fertil Steril 2016;105:256-266.

28 Howard CV, Reed M: Unbiased Stereology. Three Dimensional Measurement in Microscopy, ed 2. Oxon (UK)/New York (USA), Garland Science/BIOS Scientific Publishers, 2005, pp 33-50.

29 Lennox B, Logue DN: Tubule length and Leydig cell volume in the normal bull testis. Vet Rec 1979;104:431433.

30 Bordbar H, Esmaeilpour T, Dehghani F, Panjehshahin MR: Stereological study of the effect of ginger's alcoholic extract on the testis in busulfan-induced infertility in rats. Iran J Reprod Med 2013;11:467-472.

- 31 Gundersen HJ, Bagger P, Bendtsen TF, Evans SM, Korbo L, Marcussen N, Moller A, Nielsen K, Nyengaard JR, Pakkenberg B: The new stereological tools: disector, fractionator, nucleator and point sampled intercepts and their use in pathological research and diagnosis. APMIS 1988;96:857-881.

32 Mouton PR: Length and surface area, in Mouton PR (ed): Principles and Practices of Unbiased Stereology: An Introduction for Bioscientists. Baltimore, The Johns Hopkins University Press, 2002, pp 103-105.

33 Dalgaard M, Pilegaard K, Ladefoged O: In utero exposure to diethylstilboestrol or 4-n-nonylphenol in rats: number of sertoli cells, diameter and length of seminiferous tubules estimated by stereological methods. Pharmacol Toxicol 2002;90:59-65.

34 Pfaffl MW, Horgan GW, Dempfle L: Relative expression software tool (REST) for group-wise comparison and statistical analysis of relative expression results in real-time PCR. Nucleic Acids Res 2002;30:e36.

35 Zhang Z, Hill J, Holland M, Kurihara Y, Loveland K: Bovine Sertoli cells colonize and form tubules in murine hosts following transplantation and grafting procedures. J Androl 2008:29;418-430.

36 Kita K, Watanabe T, Ohsaka K, Hayashi H, Kubota Y, Nagashima Y, Aoki I, Taniguchi H: Production of functional spermatids from mouse germline stem cells in ectopically reconstituted seminiferous tubules. Biol Reprod 2007:76;211-217.

- 37 Honaramooz A, Megee SO, Rathi R, Dobrinski I: Building a testis: formation of functional testis tissue after transplantation of isolated porcine (Sus scrofa) testis cells. Biol Repr 2007:76;43-47.

- 38 Gassei K, Schlatt S, Ehmcke J: De novo morphogenesis of seminiferous tubules from dissociated immature rat testicular cells in xenografts. J Androl 2006:27;611-618. 


\section{Cellular Physiology Cell Physiol Biochem 2019;52:421-434

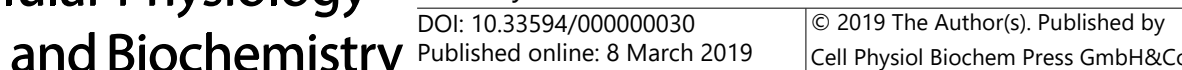 \\ Ziaeipour et al.: Sertoli Cell Transplantation}

39 Shinohara T, Orwig KE, Avarbock MR, Brinster RL: Restoration of spermatogenesis in infertile mice by sertoli cell transplantation. Biol Reprod 2003;68:1064-1071.

40 Yoshida S, Sukeno M, Nabeshima Y: A vasculature-associated niche for undifferentiated spermatogonia in the mouse testis. Science 2007;317:1722-1726.

- 41 Chiarini-Garcia H, Russell LD: High resolution light microscopic characterization of mouse spermatogonia. Biol Reprod 2001;65:1170-1178.

42 Chiarini-Garcia H, Raymer AM, Russell LD: Non-random distribution of spermatogonia in rats: evidence of niches in the seminiferous tubules. Reprod 2003;126:669-680.

43 Oatley JM, Oatley MJ, Avarbock MR, Tobias JW, Brinster RL: Colony stimulating factor 1 is an extrinsic stimulator of mouse spermatogonial stem cell self-renewal. Development 2009:136;1191-1199.

44 Tesarik J, Mendoza C, Anniballo R, Greco E: In-vitro differentiation of germ cells from frozen testicular biopsy specimens. Hum Reprod 2000;15:1713-1716.

45 Tajima Y, Watanabe D, Koshimizu U, Matsuzawa T, Nishimune Y: Insulin-like growth factor-I and transforming growth factor- $\alpha$ stimulate differentiation of type A spermatogonia in organ culture of adult mouse cryptorchid testes. Int J Androl 1995;18:8-12.

46 Hue D, Staub C, Perrard-Sapori MH, Weiss M, Nicolle JC, Vigier M: Meiotic differentiation of germinal cells in three-week cultures of whole cell population from rat seminiferous tubules. Biol Reprod 1998;59:379-387.

47 Krawetz SA, De Rooij DG, Hedger MP: Molecular aspects of male fertility. International Workshop on Molecular Andrology. EMBO Rep 2009;10:1087-1092. 